\title{
Prevalence and antimicrobial resistance of Salmonella in meat and meat products in Latvia
}

\author{
Margarita Terentjeva', Jeḷena Avsejenko², Madara Streikiša², Andra Utināne², \\ Kaspars Koval,enko', Aivars Bērziņš ${ }^{1,2}$ \\ ${ }^{1}$ Institute of Food and Environmental Hygiene, Faculty of Veterinary Medicine, Latvia University of Agriculture, \\ K. Helmana iela 8, LV-3004, Jelgava, Latvia \\ 2 Institute of Food Safety, Animal Health and Environment 'BIOR', Lejupes iela 3, LV-1067, Riga, Latvia \\ Terentjeva M, Avsejenko J, Streikiša M, Utināne A, Koval̦enko K, Bērziņš A. Prevalence and antimicrobial resistance of Salmonella in meat and \\ meat products in Latvia. Ann Agric Environ Med. 2017; 24(2): 317-321.
}

\begin{abstract}
Ibstract
Introduction and objective. Salmonella is a foodborne pathogen which causes gastrointestinal illness in consumers, and exhibits resistance to antimicrobials of veterinary and clinical significance. The aim of this study is to detect the prevalence and antimicrobial resistance of Salmonella isolates from meat in Latvia.

Materials and method. A total of 3,152 samples of raw and ready-to-eat (RTE) meats were collected during the official control and in-house control procedures in 2015. Samples were tested in accordance with ISO 6579:2002. All S. Typhimurium, $S$. Enteritidis and other isolates recovered from the official control samples (S. Derby, S. Give) were tested for antimicrobial resistance. The minimum inhibitory concentration (MIC) values were investigated in line with the requirements of the European Committee on Antimicrobial Susceptibility Testing (EUCAST).

Results. The prevalence of Salmonella was $0.8 \%$ (25/3152). The highest prevalence (1.5\%) of Salmonella was found in minced meat and meat preparations (7/481), while the lowest (0\%) in frozen meat and meat preparations (0/349) and RTE meats (0/364). The most common serovars were S. Typhimurium $(36 \%, 9 / 25)$ and S. Derby $(32 \%, 8 / 25)$. In total, 62\% (13/21) of Salmonella isolates were resistant to at least one antimicrobial agent. Altogether, $40 \%(8 / 20)$ of isolates were resistant to sulfamethoxazole, $25 \%(5 / 20)$ to nalidixic acid, ciprofloxacin, ampicillin and $20 \%(4 / 20)$ to tetracycline. All isolates were susceptible to ceftazidime, cefotaxime, meropenem, azithromycin and tigecycline. S. Typhimurium exhibited antimicrobial resistance more often (87.5\%) than other serovars.

Conclusion. The study shows that the presence of Salmonella in meat, together with the high prevalence of resistant strains, is a significant public health related issue in Latvia.
\end{abstract}

\section{Key words}

Salmonella, pork, poultry, minced meat preparations, antimicrobial resistance, Latvia

\section{INTRODUCTION}

Human salmonellosis is one of the most important foodborne infections worldwide, and the second most frequently reported in the European Union $[1,2]$. The disease is caused by Salmonella enterica subsp enterica, which is divided into more than 2,500 serovars with non-typhoidal Salmonella serovars $S$. Typhimurium, $S$. Enteritidis and $S$. Infantis were the most frequently found in clinical cases and foodstuffs in the EU $[2,3]$.

Although salmonellosis is characterized by gastrointestinal disorders, severe infections, such as bacteraemia and focal manifestations in the form of meningitis, septic arthritis, osteomyelitis, cholangitis and pneumonia, have also been reported [4]. The reported incidence of salmonellosis in the EU was 20.4 cases per 100,000 inhabitants during 2009-2013 [2]. Salmonellosis still remains the most relevant foodborne infection in Latvia with the incidence of 19.0 - 48.0 cases per 100,000 inhabitants during 2009-2013 [2].

Salmonella may be present in animals and spread from the animal host to food originating from the animal, resulting in the contamination of foodstuffs. Therefore, foods of animal

Address for correspondence: Margarita.Terentjeva, Institute of Food and Environmental Hygiene, Faculty of Veterinary Medicine, Latvia University of Agriculture, K.Helmana iela 8, LV-3004, Jelgava, Latvia

E-mail: margarita.terentjeva@llu.lv

Received: 28 November 2017; accepted: 15 March 2017; first published on June 2017 origin remain the main source of Salmonella and the disease is mostly attributed to the consumption of such contaminated products as meat, milk and eggs [2]. In previous studies, Salmonella was isolated from retail raw eggs, raw and processed milk, and meat and meat products $[5,6,7,8]$. Since salmonellosis may require systemic treatment, including antimicrobial drug therapy, the increasing resistance of Salmonella to clinically significant antimicrobial drugs is an issue for concern [4]. The antimicrobial resistance could make antibiotic therapy ineffective for patient treatment and, consequently, the resistance of Salmonella isolates should be monitored [9].

Studies on the epidemiology of Salmonella through the food chain are important for drawing out the specific patterns of distribution and antimicrobial resistance of the pathogen. Meat and its products have been reported to be important sources of Salmonella [7, 8]; therefore, the aim of this study is to study the prevalence and antimicrobial resistance of Salmonella in meats in Latvia.

\section{MATERIALS AND METHOD}

Sampling. In 2015, a total of 3,152 samples of meat and meat products were collected from slaughterhouses, meat processing plants and retail outlets. Samples were obtained during official controls and food safety monitoring of meat 
industry enterprises, including in-house control procedures. Samples included raw meat and raw meat preparations $(\mathrm{n}=1,010)$, minced meat and minced meat preparations $(n=481)$, frozen meat and frozen meat preparations $(n=349)$, slaughterhouse carcass samples $(\mathrm{n}=948)$ and ready-to-eat (RTE) meats $(\mathrm{n}=364)$.

Isolation and identification of Salmonella. Samples were investigated according to the ISO 6579:2002 [10]. An amount of $25 \mathrm{~g}$ of sample was pre-enriched in $225 \mathrm{ml}$ of Buffered Peptone Water (Biolife, Italy) for $18 \pm 2 \mathrm{~h}$ at $37^{\circ} \mathrm{C}$. After incubation, an aliquot of $0.1 \mathrm{ml}$ of suspension was transferred into $10 \mathrm{ml}$ of Rappaport-Vassiliadis soya (Biolife) and $10 \mathrm{ml}$ of Mueller-Kauffmann broths, which were incubated for $24 \mathrm{~h} \pm 3$ at $41.5^{\circ} \mathrm{C}$ and $37^{\circ} \mathrm{C}$, respectively. Then, a $10 \mu \mathrm{l}$ loop of the enriched suspension was plated out on Xylose Lysine Deoxycholate (XLD, Biolife) and Brilliant-Green Phenol-Red Lactose (BPLS, Biolife) agars, with subsequent incubation for $24 \mathrm{~h} \pm 3$ at $37^{\circ} \mathrm{C}$. After incubation, the plates were examined for the presence of Salmonella typical colonies, identified by a pink or red colour surrounded with red zone, or red colour with a black centre, on BPLS and XLD, respectively. Selected presumptive colonies were confirmed biochemically according to ISO 6579:2002 requirements [10].

Salmonella subtyping. After the confirmation of Salmonella spp., all isolates were stored at $-80^{\circ} \mathrm{C}$ in a mix of Brain-Heart Infusion (Biolife) and 20\% glycerol. Salmonella colonies were serotyped according to the White-Kauffmann-Le Minor scheme by slide agglutination with specific $\mathrm{O}$ - and $\mathrm{H}$ - antigen sera (Staten Serum Institute, Denmark). Phage typing was performed in accordance with the Colindale systems.

Detection of antimicrobial resistance. All S. Typhimurium, $S$. Enteritidis isolated from in-house and official control samples, as well as other Salmonella serovars recovered from the official control samples, were tested for the detection of antimicrobial resistance with the minimum inhibitory concentration (MIC) method [11]. Before the testing, Salmonella isolates were plated out on Nutrient agar (Biolife) and incubated for $18-24 \mathrm{~h}$ at $37^{\circ} \mathrm{C}$. The colonies were then mixed with saline until the bacterial suspension in saline with the density of $0.5 \mathrm{McF}$ arland was obtained (Nephelometer Sensititre, UK). An amount of $50 \mu \mathrm{l}$ of bacterial suspension in saline was transferred into a tube containing $11 \mathrm{ml}$ of cation-adjusted Mueller-Hinton broth (Sensititre), which was used for further testing.

For the detection of MIC, the EUVSEC panels were applied (TREK Diagnostic Systems Ltd., UK) in accordance with Commission Decision (EC) No 652/2013 [12]. The antimicrobial resistance testing panel contained ampicillin (1-64 mg/l, AMP), azithromycin (2-64 mg/l, AZT), cefotaxime (0.25-4 mg/l, CTX), ceftazidime (0.5-8 mg/l, CAZ), chloramphenicol (8-128 mg/l, C), meropenem (0.03-16 mg/l, MER), nalidixic acid (4-128 mg/l, NA), ciprofloxacin $(0.015-8 \mathrm{mg} / \mathrm{l}, \mathrm{CIP})$, tetracycline $(2-64 \mathrm{mg} / \mathrm{l}$, $\mathrm{TE})$, tigecycline $(0.25-8 \mathrm{mg} / \mathrm{l}, \mathrm{TI})$, colistin (1-16 mg/l, COL), gentamicin (0.5-32 mg/l, CN), trimethoprim (0.25-32 mg/l, $\mathrm{W}$ ) and sulfamethoxazole (8-1024 mg/l, SMX). Each well of the panel was inoculated with $50 \mu \mathrm{l}$ of bacterial suspension in Mueller-Hinton broth and the panel incubated for 18 $20 \mathrm{~h}$ at $37^{\circ} \mathrm{C}$. MIC was detected according to the EUCAST ECOFF after incubation [12].
Statistical analyses. Chi-square test was used for calculation of significance of differences between the prevalence of Salmonella in different categories of meats.

\section{RESULTS}

Prevalence of Salmonella in meats. Overall, the prevalence of Salmonella in raw meat and meat products was $0.8 \%$ $(25 / 3152)$. The highest prevalence of $1.5 \%$ was found in minced meat and meat preparations (7/481), while the lowest of $0 \%$ in frozen meat and meat preparations $0 / 349$ ) and RTE meats $(0 / 364)$. There were no differences $(\mathrm{P}>0.05)$ in the prevalence $(0.9 \%)$ of Salmonella between the raw meat and meat preparations $(9 / 1,010)$ and carcass samples $(9 / 948)$ (Tab. 1). Poultry (7.8\%) and lamb (3.4\%) slaughterhouse carcass samples, as well as minced pork and minced pork preparations $(2.8 \%)$, were the most prevalent, while the cattle

Table 1. Prevalence of Salmonella in raw meat and meat preparations in Latvia in 2015

\begin{tabular}{|c|c|c|c|}
\hline Meat category & Meat type or product & No. of samples & $\begin{array}{c}\text { No. of positive } \\
\text { samples (\%) }\end{array}$ \\
\hline \multirow{5}{*}{$\begin{array}{l}\text { Raw meat } \\
\text { and meat } \\
\text { preparations }\end{array}$} & pork & 317 & $5(1.6)$ \\
\hline & beef & 134 & $2(1.5)$ \\
\hline & poultry $^{a}$ & 392 & $2(0.5)$ \\
\hline & lamb & 14 & $0(0)$ \\
\hline & mixed meat & 153 & $0(0)$ \\
\hline Subtotal & & 1010 & $9(0.9)^{\mathrm{h}}$ \\
\hline \multirow{4}{*}{$\begin{array}{l}\text { Minced } \\
\text { meat and } \\
\text { minced meat } \\
\text { preparations }\end{array}$} & beef & 17 & $0(0)$ \\
\hline & pork & 211 & $6(2.8)$ \\
\hline & poultry & 90 & $0(0)$ \\
\hline & mixed meat ${ }^{\mathrm{b}}$ & 163 & $1(0.6)$ \\
\hline Subtotal & & 481 & $7(1.5)$ \\
\hline \multirow{4}{*}{$\begin{array}{l}\text { Frozen meat } \\
\text { and meat } \\
\text { preparations }\end{array}$} & pork & 3 & $0(0)$ \\
\hline & beef & 7 & $0(0)$ \\
\hline & poultry & 41 & $0(0)$ \\
\hline & mixed meat ${ }^{c}$ & 298 & $0(0)$ \\
\hline Subtotal & & 349 & $0(0)$ \\
\hline \multirow{4}{*}{ Carcassd } & lamb & 29 & $1(3.4)$ \\
\hline & pig & 488 & $2(0.4)$ \\
\hline & cattle & 367 & $1(0.3)$ \\
\hline & poultry & 64 & $5(7.8)$ \\
\hline \multirow[t]{3}{*}{ Subtotal } & & 948 & $9(0.9)$ \\
\hline & cooked and grilled poultry & 21 & $0(0)$ \\
\hline & smoked sausages $^{f}$ & 92 & $0(0)$ \\
\hline \multirow[t]{3}{*}{ RTE meat } & cooked sausages, frankfurters & 101 & $0(0)$ \\
\hline & smoked meat $^{g}$ & 130 & $0(0)$ \\
\hline & pâté & 20 & $0(0)$ \\
\hline Subtotal & & 364 & $0(0)$ \\
\hline Total & & 3152 & $25(0.8)$ \\
\hline \multicolumn{4}{|c|}{$\begin{array}{l}\text { b- kebab, raw sausages, cutlet, meatballs } \\
\text { c- including meat dumplings ( } n=243 \text { ) } \\
\text { d- slaughterhouse samples taken by the competent authority } \\
\text { e - chicken } \\
\text { f- cold-smoked, hot-smoked, dried and half-smoked sausages } \\
9 \text { - chicken and pork } \\
\text { h- diferences in the prevalence of Salmonella between the slaugh } \\
\text { and raw meat preparations were not significant }(P>0.05)\end{array}$} \\
\hline
\end{tabular}


carcass samples $(0.3 \%)$ the less contaminated with Salmonella (Tab. 1). The majority of Salmonella isolates originated from pork, poultry (chicken and duck) and beef, comprising $52 \%$ (13/25), $28 \%$ (7/25) and $12 \%$ (3/25), respectively (Tab. 2). Altogether, 7 Salmonella serovars were recovered from meat and meat products (Tab. 2). The most common serovars were S. Typhimurium (36\%), S. Derby (32\%) and S. Enteritidis(12\%). Other serovars were $S$. Braenderup, S. Give, S. Stanley and $S$. Virchow, which comprised $4 \%$ each $(1 / 25)$. The highest variety of serovars was found in pork, where the serovars $S$. Derby, S. Typhimurium, including monophasic variant 4, 12; i:-;,S. Enteritidis, S. Braenderup, S. Stanley and S. Virchow were confirmed. $S$. Derby was more often isolated from pork, while $S$. Typhimurium and $S$. Enteritidis from poultry (Tab. 2).

Table 2. Distribution of Salmonella serovars in different meat types in Latvia

\begin{tabular}{lcccccc}
\hline & \multicolumn{6}{c}{$\begin{array}{c}\text { Food category } \\
\text { Salmonella serovar isolates }\end{array}$} \\
\cline { 2 - 8 } & Beef & Pork & Poultry & Lamb & $\begin{array}{c}\text { Mixed } \\
\text { meats }\end{array}$ & Total (\%) \\
\hline Typhimurium & 1 & 3 & 4 & - & 1 & $9(36)$ \\
\hline Derby & 2 & 6 & - & - & - & $8(32)$ \\
\hline Enteriditis & - & 1 & 2 & - & - & $3(12)$ \\
\hline Braederup & - & 1 & - & - & - & $1(4)$ \\
\hline Give & - & - & 1 & - & - & $1(4)$ \\
\hline Stanley & - & 1 & - & - & - & $1(4)$ \\
\hline Virchow & - & 1 & - & - & - & $1(4)$ \\
\hline Non-specified 0:9,12 & - & - & - & 1 & - & $1(4)$ \\
\hline Total (\%) & $3(12)$ & $13(52)$ & $7(28)$ & $1(4)$ & $1(4)$ & $25(100)$ \\
\hline
\end{tabular}

Antimicrobial resistance of Salmonella isolated from meat. Among 21 Salmonella isolates used for antimicrobial testing, $13(62 \%)$ exhibited resistance to at least one antimicrobial agent. All isolates were susceptible to ceftazidime, cefotaxime, meropenem, azithromycin and tigecycline. Mostly, the Salmonella isolates were resistant to sulfamethoxazole (38\%, $8 / 21)$, nalidixic acid, ciprofloxacin and ampicillin $(24 \%, 5 / 21)$ and tetracycline $(19 \%, 4 / 21)$ (Tab. 3). Altogether, 5 of 13 (38\%) Salmonella isolates were resistant to one antimicrobial agent (colistin), or to one group of antimicrobial drugs (fluoroquinolones). Another 8 isolates (62\%) showed resistance to 2-4 groups of antimicrobial drugs, including 5 Salmonella multi-resistantisolates (resistant to 3 or more classes of antimicrobial drugs).
S. Typhimurium exhibited antimicrobial resistance $(89 \%$, $8 / 9)$ more often than $S$. Enteritidis $(66.6 \%, 2 / 3)$. S. Derby displayed antimicrobial resistance less frequently, and $25 \%$ $(2 / 8)$ of isolates were found to be resistant to tetracycline and sulfamethoxazole (Tab. 3). S. Enteritidis and S. Typhimurium showed resistance to the widest range of antimicrobials, and resistance to 4 groups of antimicrobial drugs was identified with resistance phenotypes AMP-SMX-W-COL and AMPCN-C-SMX, respectively (Tab. 4).

Resistant Salmonella isolates were identified in poultry (55\%; 7/13) more frequently than pork $(31 \%, 4 / 13)$, beef and minced meat (7\%; $1 / 13$ each). However, only 2 of 7 poultry isolates exhibited multi-resistance, while all the pork, beef and mixed meat isolates were multi-resistant. The most frequent resistance phenotype was TE-SMX identified in $S$. Derby in pig carcass, and AMP-TE-SMX in $S$. Typhimurium found in retail pork isolates (Tab. 4).

Table 4. Antimicrobial resistance phenotype of Salmonella in Salmonellapositive raw meat samples

\begin{tabular}{lcccc}
\hline Serovar & Source & MR (\%) & $\begin{array}{c}\text { No. of } \\
\text { isolates }\end{array}$ & Resistance phenotype \\
\hline Derby & Pig carcass & $0(0)$ & 2 & TE-SMX \\
\hline Enteritidis & Chicken meat FT 12 $^{\text {a }}$ & $0(0)$ & 1 & COL \\
\hline Goultry carcass FT 12 & $1(100)$ & 1 & AMP-SMX-W-COL- \\
\hline Give & Duck & $1(100)$ & 1 & AMP-W-SMX \\
\hline Typhimurium & $\begin{array}{c}\text { Beef carcass } \\
\text { DT 12 }\end{array}$ & $1(100)$ & 1 & AMP-CN-C-SMX \\
\hline & $\begin{array}{c}\text { Poultry carcass } \\
\text { DT 141 }\end{array}$ & $0(0)$ & 4 & NA-CIP \\
\hline Pork & $2(100)$ & 2 & AMP-TE-SMX \\
\hline & Mixed meat DT 104 & $0(0)$ & 1 & NA-CIP-SMZ
\end{tabular}

MR - resistant to three or to more than two groups of antimicrobial drugs according to EUCAST ECOFF

a- products were imported from Lithuania

b - phagotypes were not detected, one of samples was imported from Poland and contained monophasic $S$. Typhimurium

${ }^{c}$ - monophasic S. Typhimurium

\section{DISCUSSION}

The prevalence of $0.8 \%$ Salmonella in meat in the presented study was comparable with the prevalence of Salmonella in raw meats $(0.89 \%)$ and RTE products $(0 \%)$ in Estonia [8]. Minced meats and minced meat preparations (1.5\%) were mostly found to be contaminated with Salmonella; however, the reported prevalence was less than in ground meats in Greece (3.4\%), Poland (2\%), and in raw pork sausages

Table 3. Antimicrobial resistance of Salmonella serovars isolated from raw meats and meat preparations

\begin{tabular}{|c|c|c|c|c|c|c|c|c|c|c|c|c|c|c|c|}
\hline \multirow{2}{*}{$\begin{array}{l}\text { Salmonella } \\
\text { serovar }\end{array}$} & \multirow{2}{*}{$\begin{array}{l}\text { No. of } \\
\text { isolates }\end{array}$} & \multicolumn{14}{|c|}{$\begin{array}{l}\text { Antimicrobial drugs } \\
\text { No. of resistant isolates }\end{array}$} \\
\hline & & AMP & CAZ & CTX & MER & AZT & $\mathrm{COL}$ & $C$ & $\mathrm{CN}$ & NA & CIP & TE & $\mathrm{TI}$ & W & SMX \\
\hline Enteritidis & 3 & 1 & 0 & 0 & 0 & 0 & 2 & 0 & 0 & 0 & 0 & 0 & 0 & 1 & 1 \\
\hline Give & 1 & 1 & 0 & 0 & 0 & 0 & 0 & 0 & 0 & 0 & 0 & 0 & 0 & 1 & 1 \\
\hline Typhimurium & 9 & 3 & 0 & 0 & 0 & 0 & 0 & 1 & 1 & 5 & 5 & 2 & 0 & 0 & 4 \\
\hline Total & 21 & 5 & 0 & 0 & 0 & 0 & 2 & 1 & 1 & 5 & 5 & 4 & 0 & 2 & 8 \\
\hline
\end{tabular}

Key to antimicrobial drugs: AMP - Ampicillin, CAZ - Ceftazidime, CTX - Cefotaxime, MER - Meropenem, AZT - Azithromycin, COL - Colistin, C - Chloramphenicol, CN - Gentamicin, NA- Nalidixic adic, CIP-Ciprofloxacin, TE-Tetracycline, TI - Tigecycline, W- Trimethoprim, SMX - Sulfamethoxazole 
$(3.5 \%)$ in Italy $[13,14,15]$. Despite the overall prevalence of Salmonella in meats in the EU, there is a trend in its decrease which is attributable to the effective Salmonella control programme in the food chain $[16,17]$. However, the presence of Salmonella-positive raw meats, raw minced meats and preparations on the retail market still represents a concern for public health.

Poultry, lamb and pork were found to be the meats most contaminated with Salmonella. The presented findings are in good agreement with previous reports on the high prevalence of Salmonella in poultry meat and poultry carcasses $[8,14$, 18]. Pork has also been identified as an important source of Salmonella $[8,16]$. The prevalence of Salmonella in meat is attributed to the transmission of the pathogen from the animal during slaughter, indicating the significance of good hygienic practice in both pork and poultry meat production in Latvia.

The most common Salmonella serovars were S. Typhimurium (36\%), S. Derby (32\%) and S. Enteritidis (12\%). S. Enteritidis, S. Typhimurium, S. Braenderup, $S$. Stanley and $S$. Virchow were isolated from pork and poultry meat in previous studies, which is in agreement with the results of the current stuidy $[8,13,14,18]$. The identification of monophasic $S$. Typhimurium supports previous reports that pork is the main food category mostly contaminated with monophasic S. Typhimurium 4, [5], 12; i:-;. [8,19,20, 21]. $S$. Give is an unusual serovar for Latvia, and rarely reported in foods $[8,22]$. $S$. Give and monophasic $S$. Typhimuriumpositive products were imported from Lithuania and Poland, thus, the appearance of new serovars should be considered in Latvia.

Clinical salmonellosis in Latvia is mostly caused by $S$. Typhimurium and $S$. Enteritidis; however, the infections with $S$. Derby, $S$. Virchow and $S$. Stanley have also been registered [23, 24, 25]. In general, the majority of Salmonella clinical cases in Latvia have been attributed to serovars identified in meat in Latvia [25]. Additionally, the isolated serovars were among the most frequently implicated in human cases in Europe, highlighting the emergence of certain serovars in the EU, including Latvia [2]. This covers the increases in the prevalence of $S$. Derby and $S$. Stanley in food and clinical cases, and confirmation of the monophasic $S$. Typhimurium variant 4, [5], 12; i:-;, which became one of the most predominant in several European countries [2, $19,26]$.

A total of $62 \%$ of Salmonella isolates exhibited resistance to at least one antimicrobial drug. This was less than $68.9 \%$ and $84 \%$ reported in Poland and the USA, respectively, but higher than 57.7\% observed in Austria [13, 27, 28]. In comparison, the maximum number of resistances of Salmonella isolates in another study (4) was less than the 11 and 12 reported previously $[7,13]$.

Salmonella resistance to ceftazidime, cefotaxime, carbapenems was not identified in the presented study, which is in agreement with Mąka et al. [13]. In contrast, White et al. [27] reported the isolation of ceftiofur and ceftriaxoneresistant strains from ground turkey and chicken meat in the USA. The resistance to carbapenems - imipenem was reported previously in Salmonella in retail chicken meat in Germany [7]. In the present study, the resistance to sulfamethoxazole (38\%), ampicillin (24\%) nalidixic acid (24\%), ciprofloxacin (24\%) and tetracycline (19\%) was identified the most frequently. These antimicrobial drugs were among those to which Salmonella exhibited the most antimicrobial resistance, and the presented results are in line with the previously reported [5, 13, 27, 28, 29].

In Latvia, all $4 S$. Typhimurium poultry stains originated from the same farm, sharing the same phagotype DT 141 and resistance phenotype nalidixic acid-ciprofloxacin. The pattern of antimicrobial resistance of Salmonella isolates in meat may reflect the specific antibiotic usage pattern in animal husbandry. Fluoroquinolones belong to critically important antimicrobials that are applied in human medicine and treatment of severe Salmonella infection [9]. Assessment of their usage in productive poultry husbandry should be evaluated in Latvia. Altogether, 3 of 13 (23\%) Salmonella were isolated from imported meat from Lithuania and Poland, with 2 of 3 isolates were multi-resistant; therefore, the introduction of multi-resistant Salmonella serovars with imported meat should be considered.

\section{CONCLUSION}

This is the first report on the prevalence of Salmonella in meat in Latvia and shows that the presence of Salmonella in the food chain is still a problem: minced meats and minced meat preparations (1.5\%) were mostly found to be contaminated. $S$. Enteritidis, $S$. Derby and $S$. Typhimurium, including the monophasic variant, were the predominant serovars isolated from meat. Salmonella exhibited antimicrobial resistance to at least one antimicrobial agent in $62 \%$ of isolates; however, the number of multi-resistant strains was less than reported previously. This could be attributable to the low application of antimicrobial drugs in Latvia, compared to the average application in the EU. The antimicrobial resistance pattern was in agreement with that previously reported, and could reflect the specific usage of antimicrobial agents in animal husbandry in Latvia.

\section{Acknowledgements}

This study was supported by the National research program AgroBioRes Project No.5 "Resistance of microorganisms and other biological and chemical risks research procedures development and application in the food chain (RISKS)".

\section{REFERENCES}

1. Scallan E, Hoekstra RM, Angulo FJ., Tauxe RV, Widdowson MA, Roy SL, Jones JL, Griffin PM. Foodborne illness acquired in the United States-major pathogens. Emerg Infect Dis. 2011; 17: 7-15.

2. EFSA and ECDC. The European Union summary report on trends and sources of zoonoses, zoonotic agents and food-borne outbreaks in 2013. EFSA Journal. 2015; 13: 3993.

3. Popoff MY. Antigenic formulas of the Salmonellaserovars, $8^{\text {th }}$ revision. WHO Collaborating Centre for Reference and Research on Salmonella. Institute Pasteur, Paris, France. 2001.

4. Hohmann EL. Nontyphoidal salmonellosis. Clin Infect Dis. 2001; 32: 263-269.

5. Little CL, Richardson JF, Owen RJ, de Pinna E., Threlfall EJ. Campylobacter and Salmonella in raw red meats in the United Kingdom: prevalence, characterization and antimicrobial resistance pattern, 2003-2005. Food Microbiol. 2008; 25: 538-543.

6. Pochop J, Kačaniová M, Hleba L, Lejková J, Fikselová M, Kunová S,Kluz M. The StepOne real-time polymerase chain reaction detection of Salmonella sp., Salmonella enterica ser. typhimurium and enteritidis in milk and meat. J Environ Sci Health B. 2011; 46: 697-702.

7. Schwaiger K, Huther S, Hölzel C, Kämpf P, Bauer J. Prevalence of antibiotic-resistant Enterobacteriaceae isolated from chicken and pork 
meat purchases at the slaughterhouse and at retail in Bavaria, Germany. Int J Food Microbiol. 2012; 154: 206-211.

8. Kramarenko T, Nurmoja I, Kärssin A, Meremäe K, Hörman A, Roasto $\mathrm{M}$. The prevalence and serovar diversity of Salmonella in various food products in Estonia. Food Control. 2014; 42: 43-47.

9. Collignon P, Powers JH, Chiller TM, Aidara-Kane A, Aarestrup FM. World health organization ranking of antimicrobials according to their importance in human medicine: a critical step for developing risk management strategies for the use of antimicrobials in food production animals. Clin Infect Dis. 2009; 49: 132-141.

10. ISO. Microbiology of food and animal feeding stuffs. Horizontal method for detection of Salmonella spp. Geneva: International Organization for Standartization. 2002; 6579 .

11. CLSI. Performance standards for antimicrobial susceptibility testing. Clinical and Laboratory Standards Institute. 2013. Supplement M100-S22.

12. Commission Implementing Decision No 652/ 2013 of 12 November 2013 on the monitoring and reporting of antimicrobial resistance in zoonotic and commensal bacteria. http://eur-lex.europa.eu/LexUriServ/ LexUriServ.do?uri=OJ:L:2013:303:0026:0039:EN:PDF.

13. Mąka Ł, Maćkiw E, Ściezyńska H, Pawłowska K, Popowska M. Antimicrobial susceptibility of Salmonella strains isolated from retail meat products in Poland between 2008 and 2012. Food Control. 2014; 36: 199-204.

14. Manios SG, Grivokostopoulos NC, Bikouli VC, Doultsos A, Zilelidou EA, Gialitaki MA, Skandamis PN. A 3-year hygiene and safety monitoring of a meat processing plant which uses raw materials of global origin. Int J Food Microbiol. 2015; 209: 60-69.

15. D’Ostuni V, Tristezza M, De Giorgi MG, Rampino P, Grieco F, Perrotta C. Occurrence of Listeria monocytogenes and Salmonella spp. in meat processed products from industrial plants in Southern Italy. Food Control. 2016; 62: 104-109.

16. Jordan E, Egan J, Dullea C, Ward J, McGillicuddy K, Murray G, Murphy A, Bradshaw B, Leonard N, Rafter P, McDowell S. Salmonella surveillance in raw and cooked meat and meat products in the Republic of Ireland from 2002 to 2004. Int J Food Microbiol. 2006; 112: 66-70.

17. Collard JM, Bertrand S, Dierick K, Godard C, Wildemauwe C, Vermeersch K, Duculot J, Van Immerseel F, Pasmans F, Imberechts $\mathrm{H}$, Quinet C. Drastic decrease of SalmonellaEnteritidis isolated from humans in Belgium in 2005, shift in phage types and influence on foodborne outbreaks. Epidemiol Infect. 2008; 136: 771-781.

18. Pieskus J, Milius J, Michalskiene I, Zagrebneviene G. The distribution of Salmonellaserovars in chicken and humans in Lithuania. J Vet Med A. 2006 ; 53: 12-16.
19. Hopkins KL, Kirchner M, Guerra B, Granier SA, Lucarelli C, Porreto MC, Jakubczak A, Threlfall EJ, Mevius DJ. Multiresistant Salmonella serovar 4, [5], 12; i;- in Europe: a new pandemic strain? Euro Surveill. 2010: $15: 2-11$.

20. Wasyl D, Hoszowski A. Occurrence and characterization of monophasic Salmonella entericaserovar Typhimurium $(1,4,[5], 12$ : i: -) of nonhuman origin in Poland. Foodborne Pathog Dis. 2012; 9; 1037-1043.

21. Myšková P, Oslanecová L, Drahovská H, Karpíšková R. Clonal distribution of monophasic Salmonella enterica subsp. enterica serotype 4, [5], 12:i:- in Czech Republic. Foodborne Pathog Dis. 2014; 11: $664-666$.

22. Adzitey F, Rusul G, Huda N. Prevalence and antibiotic resistance of Salmonellaserovars in ducks, duck rearing and processing environment in Penang, Malaysia. Food Res Int. 2011; 45: 947-952.

23. WHO. WHO surveillance programme for control of foodborne infection and intoxication in Europe $8^{\text {th }}$ report $1999-2000$. Country Reports: Latvia. 2000. http://www.bfr.bund.de/internet/8threport/CRs/ lva.pdf. Accessed:1.10.2016.

24. Bertrand S, Rimhanen-Finne R, Weill FX, Rabsch W, Thornton L, Perevoscikovs J, van Pelt W, Heck M. Salmonella infections associated with reptiles: the current situation in Europe. Euro Surveill. 2008; 13: pii=18902008;13(24):pii=1890.

25. SPKC. Epidemiologijasbiḷetens. TheCentreforDiseasePreventionand Control. 2015; http: //www.spkc.gov.lv/infekcijas-slimibu-statistika/. Accessed: 22.04.2016.

26. Kinross P, van Alphen L, Martinez Urtaza J, Struelens M, Takkinen J, Coulombier D, Mäkelä P, Bertrand S, Mattheus W, Schmid D, Kanitz E, Rücker V, Krisztalovics K, Pászti J, Szögyényi Z, Lancz Z, Ravsch W, Pfefferkorn B, Hiller P, Mooijman K, Gossner C. Multidisciplinary investigation of a multicountry outbreak of Salmonella Stanley infections associated with turkey meat in the European Union, August 2011 to January 2013. Euro Surveill. 2014; 19(19): pii=20801.

27. White DG, Zhao S, Sudler R, Ayers S, Friedman S, Chen S, McDermott $\mathrm{PF}, \mathrm{McDermott} S$, Wagner DD, Meng J. The isolation of antibioticresistant Salmonella from retail ground meats. N Engl J Med. 2001; 345: 1147-1154.

28. Mayrhofer S, Paulsen P, Smulders FJM, Hilbert F. Antimicrobial resistance profile of five major food-borne pathogens isolated from beef, pork and poultry. Int J Food Microbiol. 2004; 97: 23-29.

29. Nogrády N, Gadó I, Tóth Á, Pászti J. Antibiotic resistance and class 1 integron patterns of non-typhoidal human Salmonella serotypes isolated in Hungary in 2002 and 2003. Int J Antimicrob Agents. 2005; 26: 126-132. 